\title{
Thermal ecology of red lionfish Pterois volitans from southeast Sulawesi, Indonesia, with comparisons to other Scorpaenidae
}

\author{
Theresa F. Dabruzzi ${ }^{1, *}$, Wayne A. Bennett ${ }^{2}$, Nann A. Fangue ${ }^{1}$ \\ ${ }^{1}$ Department of Wildlife, Fish, and Conservation Biology, University of California, Davis, California 95616, USA \\ ${ }^{2}$ Department of Biology, University of West Florida, Pensacola, Florida 32514, USA
}

\begin{abstract}
Scorpionfishes (family Scorpaenidae) occupy a wide range of thermal environments, yet little is known about the group's thermal ecology. Recent invasions by red lionfish Pterois volitans and devil firefish $P$. miles into the Atlantic Ocean and Mediterranean Sea have stimulated interest in the ability of these species to withstand thermal extremes, but current temperature data are limited to cold tolerance estimates, or employ nonstandard techniques, making it difficult to compare values across studies. Using standardized methodologies, we quantified metabolic, physiological, and behavioral thermal responses of red lionfish from the Banda Sea, Sulawesi, Indonesia, and interpret the data in light of the group's diversity and range of thermal habitats. Red lionfish acclimated at temperatures between 13 and $32^{\circ} \mathrm{C}$ exhibit a thermal scope of nearly $25^{\circ} \mathrm{C}$. The resulting thermal niche is moderately large, allowing lionfish to exploit a wide range of thermal habitats, from mid-Atlantic coastal waters to hyperthermal tropical mangroves and tidepools. Although lionfish prefer temperatures of $\sim 23^{\circ} \mathrm{C}$, they acclimate to the high temperature of a cycling thermoperiod. This feature, along with their comparatively low temperature sensitivity (metabolic temperature quotient $<2$ ), likely permits lionfish to limit energetic costs during forays into warmer waters. Although lionfishes are considered to be a tropical group, they exhibit a number of thermal tolerance characteristics that allow them to persist in some surprisingly cool environments. Modeling thermal strategies used by red lionfish may provide new insights to the range and variability of thermal adaptations of scorpaenid fishes in general.
\end{abstract}

KEY WORDS: Thermal tolerance polygon - Temperature quotient - Temperature preference · Metabolic rate $\cdot$ Critical thermal methodology

\section{INTRODUCTION}

Scorpionfishes (family Scorpaenidae) are a diverse and widespread group with representatives in the Red Sea, western and southern Pacific Ocean, eastern Atlantic Ocean, and Caribbean Sea (Nelson 2006). Scorpaenid systematics have undergone substantial revision over the last decade, and while some areas remain unresolved, the most recent work by Eschmeyer et al. (2016) lists 376 valid species in the family. Most scorpionfishes exhibit a somewhat compressed body form with distinctively large heads

*Corresponding author: tfdabruzzi@ucdavis.edu covered by protective ridges and spines. Protective spines are also prominent on the dorsal, pelvic, and anal fins of many species, and are often venomous, capable of delivering powerful defensive stings. Scorpaenids are proficient top predators that play a vital role in nutrient cycling and shaping prey assemblages in their respective habitats (Hixon \& Beets 1993). Lionfishes, firefishes, and turkey fishes (subfamily Pteroinae), for example, are indiscriminant suction feeders that prey on a wide variety of small, midwater crustaceans and fish (Morris \& Akins 2009, Eddy et al. 2016, Harms-Tuohy et al. 2016), whereas

(C) The authors 2017. Open Access under Creative Commons by Attribution Licence. Use, distribution and reproduction are unrestricted. Authors and original publication must be credited. 
the crouchers (subfamily Caracanthinae), stonefishes, and scorpionfishes (subfamily Scorpaeninae) are cryptic ambush predators that consume a broad range of smaller, benthic prey. By limiting overall prey abundance, scorpionfishes indirectly influence other large predator populations (Albins \& Hixon 2013, Ingeman 2016).

While scorpaenids play a key ecological role in their native environments, introductions into habitats outside their native range can have deleterious effects on the local ecology (Albins \& Hixon 2008, Lesser \& Slattery 2011, Hackerott et al. 2013). At least 3 scorpaenid species are known to have successfully colonized novel habitats. The black scorpionfish Scorpaena porcus from the Red Sea has established reproducing populations in the Mediterranean following the opening of the Suez Canal (Spanier 2000, Zenetos et al. 2005, Arculeo \& Brutto 2014), and aquarium-released red lionfish Pterois volitans and devil firefish $P$. miles have established permanent populations along the US Eastern Seaboard, Gulf of Mexico, Caribbean Sea, and the eastern coasts of Central and South America over the last $30 \mathrm{yr}$ (Schofield 2009). Introduced lionfish have dramatically reduced the abundance of benthic invertebrates (Layman et al. 2014), as well as forage and predator fish populations (Albins \& Hixon 2008, Green et al. 2012, Albins \& Hixon 2013). Furthermore, red lionfish on some Caribbean reefs have attained densities much higher than those seen in their native range (Green \& Côté 2009, Darling et al. 2011). Higher lionfish concentrations in the Caribbean have been attributed to increased growth rates (Jud \& Layman 2012, Albins \& Hixon 2013, Pusack et al. 2016), iterative spawning (Edwards et al. 2014), and early onset of reproduction (Edwards et al. 2014), all of which are likely to be exacerbated by rising sea surface temperatures (Raitsos et al. 2010). The detrimental effects on prey populations from lionfish introductions into novel ecosystems are widespread and thought to be related to increased predatory efficiency due to prey naivety (Albins \& Lyons 2012, Lönnstedt et al. 2014), and a lack of predators actively feeding on introduced populations (Allen \& Eschmeyer 1973, Pimiento et al. 2012).

The ability of scorpaenid fishes to occupy a variety of habitat types, both native and novel, is due in large part to their ability to tolerate a wide range of environmental conditions (Cure et al. 2014, Schofield et al. 2014). While sculpins were at one time included as part of the Scorpaenidae (Nelson 2006), the current classification scheme by Eschmeyer et al. (2016) includes no wholly freshwater members. Approximately
$3 \%$ of scorpaenids regularly enter brackish environments (Eschmeyer et al. 2016), with some species tolerating salinities as low as 5\% (Jud et al. 2015, Schofield et al. 2015). Juvenile red lionfish, for example, may use brackish seagrass or mangrove habitats as nursery refugia during development (Barbour et al. 2010, Claydon et al. 2012), and in some locations, adults can be found feeding in low salinity intertidal zones on small fish and crustaceans (Vijay Anand \& Pillai 2007, Kulbicki et al. 2012, Pimiento et al. 2012, Jud et al. 2015). No study to date has quantified salinity tolerance of lionfish egg masses or larvae, although Johnston \& Purkis (2015) presented convincing evidence that hurricanes are responsible for breaching the strong northerly flow of the Florida Current, thereby allowing genetic mixing between Floridian and Bahamian populations. If hurricanes are indeed a vector for spreading invasive lionfish from Florida to the Bahamas, then it might be reasonable to assume that eggs and larvae must also be somewhat tolerant of low salinity if they are to survive inundation by rainwater during transport. Scorpionfishes are also distributed over a wide range of depths, from rocky intertidal pools that become isolated during low tide (Beckley 2000), to soft-bottom deep-sea zones (Kulbicki et al. 2012, Nuttall et al. 2014) over $800 \mathrm{~m}$ below the surface (Hureau \& Litvinenko 1986). Ichthyofaunal surveys and field guides often list depths over which various scorpionfish species may be found (e.g. Paulin 1982, Steene 2003, Butler et al. 2012), but annotations of water temperatures are seldom if ever reported (Whitfield et al. 2014).

Early fossil records suggest that scorpionfishes originated in warm marine waters sometime during the Paleogene Period 65 to 23 million years ago (Berg 1958). While the greatest diversity of contemporary scorpionfishes is still found on tropical reef or reefassociated habitats (Eschmeyer et al. 2016, also see Motomura et al. 2011), several hypothermic scorpaenids regularly exploit cool or even cold-water zones in various seas and oceans. The California scorpionfish Scorpaena guttata, for example, spends its entire life in cold waters along the southern Baja California Sur (Eschmeyer et al. 1983, Love et al. 1987 ) at temperatures as low as $12.5^{\circ} \mathrm{C}$ (Norton \& Mason 2003). Similarly, the black scorpionfish found on cold rocky bottoms at depths to $800 \mathrm{~m}$ in the eastern Atlantic, Black Sea, and Mediterranean Sea (Hureau \& Litvinenko 1986) has been collected in winter at temperatures of $8.8^{\circ} \mathrm{C}$ (Bilgin \& Çelik 2009), making it one of the most cold-tolerant scorpionfishes known. Even some tropical scorpaeanid populations may 
regularly encounter cold water in parts of their natural or introduced range. Red lionfish, luna lionfish $P$. lunulata, and peppermint lionfish Dendrochirus bellus (= Brachirus bellus), for example, routinely encounter winter temperatures at or below $15^{\circ} \mathrm{C}$ off the southern Pacific coast of Japan (Tokioka 1961, Araga \& Tanase 1968). Likewise, red lionfish and devil firefish, originally introduced in Florida, have spread northward along the US mid-Atlantic coast to North Carolina, where they experience winter low temperatures of 11 to $16^{\circ} \mathrm{C}$ (NOAA 2016). Although juveniles are occasionally carried on currents as far north as New York (Meister et al. 2005), it is unlikely that either species survives the area's prolonged winter water temperatures of 2 to $10^{\circ} \mathrm{C}$ (NOAA 2016).

Several publications have suggested that cold temperatures are a major limiting factor for lionfishes within their native range (Johnston \& Purkis 2011) as well as in areas where lionfish species have been accidently introduced (Kimball et al. 2004, Johnston \& Purkis 2014). Indeed, it was widely believed that the northward spread of the tropical invasive lionfishes in the US would be slowed somewhat at higher latitudes by lower water temperatures (Kimball et al. 2004, Johnston \& Purkis 2011). Nonetheless, lionfish expansion into waters of the mid-Atlantic coast occurred more quickly than most biologists anticipated (Whitfield et al. 2002). Several attributes contributing to lionfish plasticity, including their indiscriminant diet, ability to exploit a wide range of depths, and tolerance of a wide range of water quality conditions, have been systematically explored within the larger context of general scorpaenid life history (Cure et al. 2014). The study of lionfish thermal ecology, however, has been largely restricted to low temperature tolerance measurements that are used to predict lethal temperatures limiting the range of red lionfish colonization. Although this approach produces a clear endpoint, focus on a single value overlooks nuances and adaptive characteristics that make these fishes so successful. Understanding the range and scope of a fish's thermal niche, and how it compares to other species, provides a context for understanding not only thermal relationships, but also related features such as temperature preference and metabolic thermal sensitivity. Without question, previous cold tolerance estimates have been useful in predicting range limitations (Kimball et al. 2004, Morris \& Whitfield 2009) and overwintering potential of Atlantic and Caribbean Sea lionfish populations (Ferreira et al. 2015). Nevertheless, temperature responses of lionfish originating from a small founder group (Hamner et al. 2007, Freshwater et al. 2009, Betancur-R. et al. 2011) may not reflect novel thermal features seen in tropical wild-stock populations that regularly experience temperatures below $15^{\circ} \mathrm{C}$ at the fringes of their distributions (Tokioka 1961, Araga \& Tanase 1968). An investigation of native populations of scorpionfish could provide further insights into the thermal ecology and temperature adaptations of this important and widespread fish group.

The purpose of our study was to evaluate temperature-mediated physiological, behavioral, and metabolic responses of red lionfish native to the Banda Sea, Sulawesi, Indonesia. The Banda Sea population was chosen because recent genetic analyses suggest that the initial founding population of lionfish released along the Florida Atlantic coast originated at or near this area (Hamner et al. 2007, Freshwater et al. 2009). In addition, the red lionfish is one of the most widely distributed, regionally abundant, and best studied members of the family Scorpaenidae, and a better understanding of the thermal ecology of a native population would add comparative value to current and future thermal data from introduced groups. Specific objectives of our work were to (1) estimate the thermal acclimation range as well as upper and lower thermal tolerance limits of red lionfish acclimated to constant and cycling temperatures, (2) use the acclimation and tolerance data to produce a thermal tolerance niche for the native population, (3) quantify the thermal preference and metabolic temperature sensitivity of this species, and (4) interpret the thermal ecology data in relation to lionfish activity in its natural habitat, and perhaps provide a better understanding of invasion ecology.

\section{MATERIALS AND METHODS}

\section{Red lionfish collection and holding conditions}

Eighty adult red lionfish with mean $( \pm \mathrm{SD})$ standard length $9.9( \pm 1.4) \mathrm{cm}$, and mass of $42.0( \pm 21.8) \mathrm{g}$ were collected from shallow back-reef habitats off Hoga Island in the Banda Sea, southeast Sulawesi, Indonesia $\left(05^{\circ} 27^{\prime} 53^{\prime \prime} \mathrm{S}, 123^{\circ} 46^{\prime} 33^{\prime \prime} \mathrm{E}\right)$. Fish were placed into a $160 \mathrm{l}$ insulated cooler and immediately transported to the Hoga Island Research Laboratory. Ten field-acclimatized lionfish were held for $48 \mathrm{~h}$ at field temperatures and then placed into metabolic trials. The remaining 70 fish were transferred into a 4001 holding tank containing aerated seawater at $26.5( \pm 0.5)^{\circ} \mathrm{C}$ and salinity $34( \pm 2)$. Daily measures of water temper- 
ature were made using an Oakton model 300 digital thermometer and salinity was measured using a handheld refractometer. Measures of $\mathrm{pH}$, ammonia, and nitrite were monitored at 3 to 5 d intervals using standard aquarium test kits. Water quality was maintained by continuous, moderate aeration and daily $20 \%$ water exchanges within $0.5^{\circ} \mathrm{C}$ of the current set temperature. Lionfish were held under a natural 12:12 light:dark diel photoperiod and were fed a diet of live fish every other day. Once fish began actively feeding, they were randomized and placed into temperature treatment groups, with each fish used in only 1 experimental trial. The water quality regimen and feeding schedule was continued for lionfish in experimental treatments during acclimation; however, fish were not fed $48 \mathrm{~h}$ prior to or during experimental trials. The lone exception were lionfish in the chronic temperature experiments, which, owing to the extended experimental times, were fed during trials. Upon completion of experiments, all lionfish were released at their site of capture.

\section{Critical thermal methodology}

Critical thermal methodology (CTM) was used to estimate critical thermal minimum (CTmin) and critical thermal maximum (CTmax) values for red lionfish in constant temperature acclimation experiments, and cycling thermoperiod experiments (Cowles \& Bogert 1944, Becker \& Genoway 1979, Paladino et al. 1980, Beitinger et al. 2000). For each trial, a single lionfish was transferred to an insulated CTM chamber $(38 \times 30 \times 22 \mathrm{~cm}, \sim 251$ capacity) filled with 20.51 of clean seawater within $0.5^{\circ} \mathrm{C}$ of the treatment temperature. Lionfish were allowed to habituate to chamber conditions for $30 \mathrm{~min}$, after which chamber water was heated (Finnex, 300-W submersible titanium heater) or chilled (Aqua Euro, $184 \mathrm{~W}$ aquarium chiller) at a constant rate of $0.2^{\circ} \mathrm{C} \mathrm{min}^{-1}$ until loss of equilibrium was observed (Cox et al. 1974, Becker \& Genoway 1979, Beitinger et al. 2000). CTmax and/or CTmin of lionfish in a given treatment were calculated as the arithmetic mean of the collective replicate endpoint temperatures (Cox et al. 1974, Becker \& Genoway 1979, Beitinger et al. 2000). Following trials, fish were weighed (wet mass $\pm 0.1 \mathrm{~g}$ ), measured (standard length $\pm 0.1 \mathrm{~cm}$ ), and returned to their previous acclimation temperature to recover. Differences in lionfish mean CTM or mass values were explored within treatments using 1-way ANOVA followed by Tukey's multiple range test where appropriate $(\alpha=0.05)$.

\section{Upper and lower chronic temperature experiments}

Red lionfish upper and lower acclimation limits were estimated as high and low chronic temperatures, respectively (Beitinger et al. 2000, Dabruzzi et al. 2013). During chronic trials, 6 replicate groups of 3 lionfish each were placed into insulated 601 temperature treatment tanks (Table 1). Lionfish in treatment tanks were held for $24 \mathrm{~h}$ at $26.5^{\circ} \mathrm{C}$, after which temperatures in 3 of the tanks were increased (Finnex 300-W titanium heaters), and the remaining 3 tanks were decreased (Aqua Euro Corporation, $184 \mathrm{~W}$ water chiller) $1^{\circ} \mathrm{C} \mathrm{d}^{-1}$ until fish lost equilibrium (Beitinger et al. 2000). The upper and lower mean temperature at equilibrium loss was determined for each replicate tank, and the high and low chronic limit for the population was estimated as the respective replicate grand mean. Mean masses of lionfish in upper and lower chronic trials were compared with Student's $t$-test $(\alpha=0.05)$.

\section{CTmax and CTmin experiments}

Tolerance responses of red lionfish acclimated to constant temperatures were determined by quantifying respective CTmax and CTmin of fish groups acclimated at constant treatment temperatures of 17.8, 23.0, 29.0, or $31.1( \pm 0.4)^{\circ} \mathrm{C}$. Each temperature treatment consisted of an insulated water bath containing 4 replicate 601 tanks housing 2 lionfish each. One fish in each treatment tank was used in a high temperature tolerance trial, while the other was used in a low temperature tolerance trial (i.e. 4 replicate lionfish per treatment, see Table 1). Lionfish in all treatment tanks were held for $24 \mathrm{~h}$ at $26.5^{\circ} \mathrm{C}$, after which water temperatures were increased (Finnex, 300-W titanium heaters) or decreased (Aqua Euro, $184 \mathrm{~W}$ aquarium chiller) $1^{\circ} \mathrm{C} \mathrm{d}^{-1}$ until the appropriate treatment temperature was reached. Upon reaching their treatment temperatures, lionfish groups were held for an additional $14 \mathrm{~d}$ before undergoing upper and lower temperature tolerance trials (Fangue et al. 2014).

\section{CTmax thermal period experiment}

CTmax was determined for 5 groups of 2 red lionfish acclimated for $14 \mathrm{~d}$ to a $24 \mathrm{~h}$ thermoperiod with respective upper and lower thermal limits of 30.3 and $24.3( \pm 0.5)^{\circ} \mathrm{C}($ Table 1$)$. A triangular waveform cycling pattern was chosen because it best simulates 
Table 1. Summary of red lionfish Pterois volitans experimental design, measurement endpoint, and temperature acclimation for 7 experiments using a total of 80 red lionfish collected from reef environments in the Banda Sea, southeast Sulawesi, Indonesia. Replication unit is the number of lionfish used in each replicate

\begin{tabular}{|c|c|c|c|c|c|c|c|}
\hline Experiment & Treatment & $\begin{array}{l}\text { Treatment } \\
\text { groups }\end{array}$ & $\begin{array}{c}\text { Treatment } \\
\text { replications }\end{array}$ & $\begin{array}{c}\text { Replication } \\
\text { unit }\end{array}$ & $\begin{array}{l}\text { Measurement } \\
\text { endpoint }\end{array}$ & $\begin{array}{l}\text { Total fish in } \\
\text { experiment }\end{array}$ & $\begin{array}{l}\text { Acclimation } \\
\text { regimen }\end{array}$ \\
\hline $\begin{array}{l}\text { High chronic } \\
\text { temperature }\end{array}$ & $\begin{array}{l}1^{\circ} \mathrm{C} \mathrm{d}^{-1} \text { tempera- } \\
\text { ture increase }\end{array}$ & 1 & 3 & 3 & $\begin{array}{l}\text { Loss of equilibrium } \\
\text { temperature }\end{array}$ & 9 & $\begin{array}{l}14 \mathrm{~d} \text { acclimation } \\
\text { at } 26.5^{\circ} \mathrm{C}\end{array}$ \\
\hline $\begin{array}{l}\text { Low chronic } \\
\text { temperature }\end{array}$ & $\begin{array}{l}1^{\circ} \mathrm{C} \mathrm{d}^{-1} \text { tempera- } \\
\text { ture decrease }\end{array}$ & 1 & 3 & 3 & $\begin{array}{l}\text { Loss of equilibrium } \\
\text { temperature }\end{array}$ & 9 & $\begin{array}{l}14 \mathrm{~d} \text { acclimation } \\
\text { at } 26.5^{\circ} \mathrm{C}\end{array}$ \\
\hline $\begin{array}{l}\text { Critical thermal } \\
\text { maximum }\end{array}$ & $\begin{array}{l}\text { Constant } \\
\text { temperature }\end{array}$ & 4 & 4 & 1 & $\begin{array}{l}\text { Loss of equilibrium } \\
\text { temperature }\end{array}$ & 16 & $\begin{array}{l}14 \mathrm{~d} \text { acclimation } \\
\text { at } 17.8,23.0, \\
29.0 \text {, or } 31.1^{\circ} \mathrm{C}\end{array}$ \\
\hline $\begin{array}{l}\text { Critical thermal } \\
\text { minimum }\end{array}$ & $\begin{array}{l}\text { Constant } \\
\text { temperature }\end{array}$ & 4 & 4 & 1 & $\begin{array}{l}\text { Loss of equilibrium } \\
\text { temperature }\end{array}$ & 16 & $\begin{array}{l}14 \mathrm{~d} \text { acclimation } \\
\text { at } 17.8,23.0 \\
29.0 \text {, or } 31.1^{\circ} \mathrm{C}\end{array}$ \\
\hline $\begin{array}{l}\text { Cycling thermal } \\
\text { maximum }\end{array}$ & $\begin{array}{l}24.3-30.3^{\circ} \mathrm{C} \\
\text { thermoperiod }\end{array}$ & 1 & 5 & 2 & $\begin{array}{l}\text { Loss of equilibrium } \\
\text { temperature }\end{array}$ & 10 & $\begin{array}{l}14 \mathrm{~d} \text { thermoperiod } \\
\text { acclimation }\end{array}$ \\
\hline $\begin{array}{l}\text { Thermal } \\
\text { preference }\end{array}$ & $\begin{array}{l}20.0-27.0^{\circ} \mathrm{C} \\
\text { thermal gradient }\end{array}$ & 1 & 10 & 1 & $\begin{array}{l}\text { Final thermal } \\
\text { preferendum }\end{array}$ & 10 & $\begin{array}{l}14 \mathrm{~d} \text { acclimation } \\
\text { at } 26.5^{\circ} \mathrm{C}\end{array}$ \\
\hline $\begin{array}{l}\text { Temperature } \\
\text { quotient }\end{array}$ & $\begin{array}{l}\text { Acute } 8^{\circ} \mathrm{C} \\
\text { temperature } \\
\text { change }\end{array}$ & 1 & 10 & 1 & Metabolic rate & 10 & $\begin{array}{l}\text { Matched pairs } \\
\text { design on field } \\
\text { acclimatized fish }\end{array}$ \\
\hline
\end{tabular}

thermal conditions seen in shallow back-reef zones during low midday spring tides (Bennett 2010). During acclimation, 5 replicate 601 tanks housing 2 lionfish each were exposed to a $4 \mathrm{~h}$ temperature decrease (Aqua Euro, $184 \mathrm{~W}$ aquarium chiller) between 00:00 and 04:00 h, and a $4 \mathrm{~h}$ increase (2 submersible 300-W Finnex, titanium heaters) between 12:00 and 16:00 h local time. Treatment temperatures passively increased or decreased between cooling and heating intervals.

\section{Thermal niche determination}

Red lionfish critical and chronic temperature tolerance data were used to define the species' ecological thermal niche, graphically expressed as a quadrilateral polygon (Bennett \& Beitinger 1997, Fangue \& Bennett 2003, Dabruzzi et al. 2013). The lateral polygon boundaries were determined by the lower and upper chronic tolerance limits. Simple linear regression was used to model the relationship of CTmax or CTmin on acclimation temperature and the resulting regression lines were extrapolated to the upper and lower chronic temperature limits to define the tolerance polygon upper and lower boundaries. The resulting figure was expressed quantitatively using the areal units of ${ }^{\circ} \mathrm{C}^{2}$. Total polygonal area was further divided into an intrinsic tolerance zone (i.e. ther- mal tolerance independent of thermal acclimation) as well as upper and lower acquired tolerance zones (i.e. thermal tolerance gained through acclimation) by dividing the polygon with horizontal lines originating at the intersection of the CTmin and CTmax regressions at their respective upper and lower chronic limits.

\section{Thermal preference experiment}

Temperature preference experiments were used to identify the final thermal preferendum (see Coutant 1977, Reynolds \& Casterlin 1979, Dabruzzi et al. 2013) of 10 lionfish acclimated for $3 \mathrm{wk}$ to laboratory temperatures of $26.5( \pm 0.5)^{\circ} \mathrm{C}$ (Table 1). Thermal preference trials were run in a flow-through temperature gradient constructed of closed-cell Styrofoam ${ }^{\circledR}$ (outside dimensions: $244 \times 40 \times 23 \mathrm{~cm}, 2.45 \mathrm{~cm}$ wall thickness, 1831 capacity), and divided into identical, interconnected sections by 9 alternating baffles (Fig. 1). While in use, the thermal gradient contained 1451 of seawater with a water depth of $\sim 19 \mathrm{~cm}$. The temperature gradient was established by running chilled seawater at $14^{\circ} \mathrm{C}$ (Aqua Euro, $184 \mathrm{~W}$ aquarium chiller) from an insulated reservoir into 1 end of the chamber at a rate of $6 \mathrm{l} \mathrm{h}^{-1}$. Water moving through the chamber was progressively heated in each section (Finnex submersible 50-W titanium 


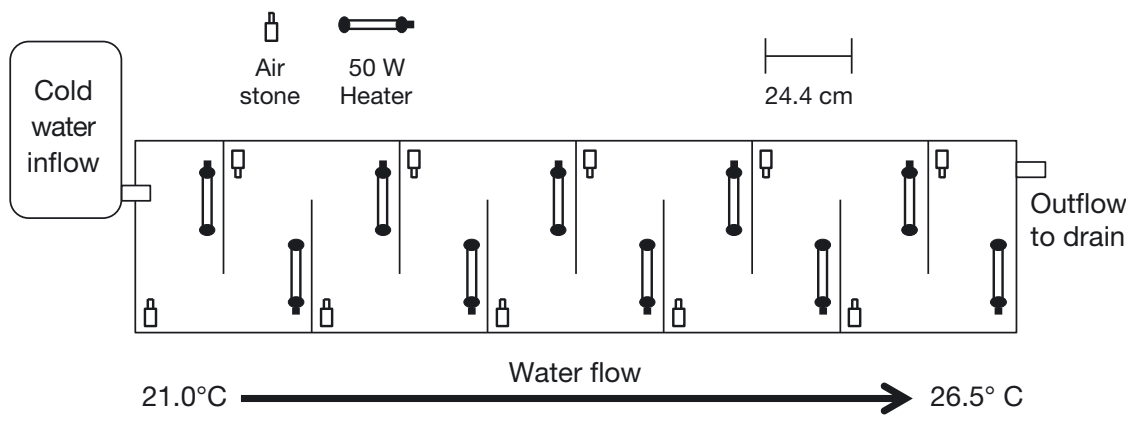

Fig. 1. Top-down view of the thermal gradient chamber used to quantify red lionfish Pterois volitans thermal preference. Cool water entering the chamber is aerated and gradually heated from 21.0 to $26.5^{\circ} \mathrm{C}$ as it passes over a series of air stones and $50 \mathrm{~W}$ titanium heaters

heaters), while air stones in each section mixed the water to prevent vertical temperature stratification. The gradient temperature ranged from 20.0 to $27.0^{\circ} \mathrm{C}$ and was representative of monthly average thermal conditions experienced by lionfish in back-reef environments of southeast Sulawesi, Indonesia (Eme \& Bennett 2009). Water flow and chamber orientation effects that could influence fish preference for a particular chamber location were minimized by maintaining a consistent, low flow rate and by reversing the direction of flow through the chamber between trials (Coutant 1977). For each trial, a single fish was placed into a randomly chosen section of the thermal gradient chamber, and data collection started after the first hour. Water temperatures were then logged over the following $24 \mathrm{~h}$ period. Water temperature selected by each fish was recorded at 3 min intervals by an iButton ${ }^{\circledR}$ temperature logger (Thermochron, Model DS1922L) attached to the base of the dorsal fin with a single suture. Mean, median, and modal temperatures for each lionfish were determined from the logger data, and all 3 endpoints were estimated as the grand mean of the individual values (Reynolds \& Casterlin 1979, Dabruzzi et al. 2013).

\section{Respirometry experiments and temperature quotient $\left(Q_{10}\right)$ determination}

Standard flow-through respirometry techniques (Steffensen 1989, Cech 1990) were used to determine routine resting metabolic rates of 10 field-acclimatized red lionfish (Table 1). Captured fish were fasted at approximate mean field temperatures of $26.5 \pm$ $0.5^{\circ} \mathrm{C}$ for $48 \mathrm{~h}$ prior to experimental trials to ensure that measurements were taken in a post absorptive state (Hopkins \& Cech 1994, Di Santo \& Bennett 2011). For each trial, a single lionfish was placed into a glass cylindrical respirometer $(15 \mathrm{~cm} \mathrm{ID} \times 14.0 \mathrm{~cm}, 2.51$ capacity) with a transparent polychloroethanediyl lid $(1.6 \mathrm{~cm}$ thickness, density $=$ $1.45 \mathrm{~g} \mathrm{~cm}^{-3}$ ) sealed with a silicone gasket (Stevens 1992). The respirometer was submerged into a constant temperature water bath, and filtered seawater $(30 \mu \mathrm{m}$ plankton net) was supplied to the chamber via a constant-pressure head box. Fish were habituated overnight (Hopkins \& Cech 1994, Neer et al. 2006) as fully saturated seawater at $26.5 \pm 0.5^{\circ} \mathrm{C}$ flowed freely through the respirometer chamber. At 07:00 $\mathrm{h}$ the following morning, any air pockets were eliminated from the respirometer (Carlson \& Parsons 1999), water temperature was set to the appropriate experimental level, and the flow rate adjusted based on fish body mass so that the difference between inflow and outflow oxygen concentration $\left(\mathrm{mg} \mathrm{l}^{-1}\right)$ remained at or above $85 \%$ saturation (Cech 1990). Fish were held at the new flow conditions for $\sim 1.5 \mathrm{~h}$, to ensure that conditions in the respirometer had reached equilibrium (Steffensen 1989). Temperature and oxygen concentrations of inflow and outflow water streams were then recorded at $30 \mathrm{~min}$ intervals over the next $5 \mathrm{~h}$ using Yellow Springs Instruments oxygen meters (model 550A), with oxygen values confirmed by Winkler titration (Cox 1990). Metabolic rates of each lionfish were measured at $20.3( \pm 0.3)$ and $28.4( \pm 0.4)^{\circ} \mathrm{C}$. To avoid directional confounding effects, metabolic measurements for half of the experimental trials were determined first at $20.3^{\circ} \mathrm{C}$ and again following an acute temperature increase to $28.4^{\circ} \mathrm{C}$, while remaining fish were subjected to the reciprocal temperature protocol. The respirometer, including tubing and head box, was thoroughly washed with antibacterial soap and left to air dry between trails. A blank respirometry trial (identical in all respects but without the fish) was run after the fifth and tenth trial, and the mean blank value was used to correct for non-fish oxygen uptake by subtracting the treatment blank value from the total. Total oxygen consumption rates were calculated from the equation (Cech 1990):

$$
\dot{M}_{2}=\left(\mathrm{Co}_{2(\mathrm{i})}-\mathrm{Co}_{2(\mathrm{o})}\right) \dot{V}_{\mathrm{w}}
$$

where $\dot{M}_{2}$ is routine resting oxygen consumption rate $\left(\mathrm{mg} \mathrm{min}^{-1}\right), \mathrm{Co}_{2(\mathrm{i})}$ is oxygen concentration of inflow water $\left(\mathrm{mg} \mathrm{l}^{-1}\right), \mathrm{Co}_{2(\mathrm{o})}$ is oxygen concentration of outflow water $\left(\mathrm{mg} \mathrm{l}^{-1}\right)$, and $\dot{V}$ is the water flow rate through the respirometer $\left(1 \mathrm{~min}^{-1}\right)$. 
Differences between metabolic rates measured at 20.3 and $28.4^{\circ} \mathrm{C}$ were explored using Student's paired, 1-tailed $t$-test. In addition, a temperature quotient, or $Q_{10}$, was calculated to assess the effects of increasing temperature on lionfish metabolism. The $Q_{10}$ is an index of thermal sensitivity, and was estimated using the following equation (SchmidtNielsen 1997):

$$
Q_{10}=\left(K_{2} / K_{1}\right)^{\frac{10}{T_{2}-T_{1}}}
$$

where $Q_{10}$ is the temperature quotient and $K_{2}$ and $K_{1}$ are mean metabolic rates at temperatures $T_{2}\left(28.4^{\circ} \mathrm{C}\right)$ and $T_{1}\left(20.3^{\circ} \mathrm{C}\right)$, respectively.

\section{RESULTS}

\section{Tolerance responses of red lionfish to chronic temperature changes}

Upper and lower chronic temperature trials expose fish to changing water temperatures that allow thermal acclimation rates to keep pace with the heating or cooling rate (Beitinger et al. 2000, Dabruzzi et al. 2013). Lionfish in chronic temperature experiments exposed to an approximate $1^{\circ} \mathrm{C} \mathrm{d}^{-1}$ temperature change exhibited a high chronic temperature of $32.0^{\circ} \mathrm{C}$, and a low chronic temperature of $12.6^{\circ} \mathrm{C}$ (Table 2), defining a relatively wide acclimation zone covering more than $19^{\circ} \mathrm{C}$. Lionfish used in chronic trials were similar in size (Student's $t$-test, $t_{4}=0.898, \mathrm{p}=$ 0.420 ) and exhibited no obvious differences in behavior. Fish were generally observed moving slowly around their tank, and both groups were more active when feeding. As lionfish neared their chronic limit, however, those at high temperatures consumed more fish more quickly than those approaching their low chronic limit.

\section{Tolerance responses to constant temperature acclimation}

Lionfish acclimated at constant temperatures between 17.8 and $31.1^{\circ} \mathrm{C}$ exhibited pronounced and well-defined upper and lower acclimation responses (Table 2). Mean lionfish mass values were statistically similar (1-way ANOVA, $F_{4,37}=1.7$, $\mathrm{p}=0.164$ ) across all CTmin and CTmax treatment groups. Regression analysis of CTmax values on acclimation temperature revealed a highly significant relationship $\left(F_{1,15}=189.4, \mathrm{p}<0.0001\right)$ defined by the following model:

$$
\text { CTmax }=27.751+\text { acclimation temp. } \times 0.345
$$

Likewise, regression analysis of CTmin data found a highly significant relationship between acclimation temperature and CTmin values $\left(F_{1,15}=229.1, \mathrm{p}<\right.$ 0.0001):

$$
\text { CTmin }=4.610+\text { acclimation temp. } \times 0.295
$$

Both CTmax and CTmin models show a strong relationship between acclimation temperature and heat or cold tolerance. Student's $t$-test revealed the 2 slope values to be statistically similar $\left(t_{24}=0.154, \mathrm{p}=\right.$ $0.165)$. Regression values $\left(\mathrm{r}^{2}\right)$ showed that 93.1 and $94.2 \%$ of the variability in respective CTmax and CTmin can be explained by changes in acclimation temperature alone. Furthermore, the regression slopes suggest that for every $1^{\circ} \mathrm{C}$ increase in acclimation temperature, red lionfish accrued $0.36^{\circ} \mathrm{C}$ of heat tolerance and lost $0.30^{\circ} \mathrm{C}$ of cold tolerance.

\section{Tolerance responses to cycling temperatures}

The heat tolerance limit for lionfish exposed to a $24 \mathrm{~h}$ cycling thermoperiod of 24.0 to $30.5^{\circ} \mathrm{C}$ sug-

Table 2. Summary data for chronic and critical thermal tolerance values, thermal preference, and metabolic rate of red lionfish Pterois volitans exposed to various temperature treatment regimes. Data are mean $\pm \mathrm{SD}$. Statistical comparisons were made between treatments within critical thermal maxima or minima experiments and values sharing superscripts are statistically indistinct

\begin{tabular}{|lcccc|}
$\begin{array}{l}\text { Acclimation } \\
\text { temp. }\left({ }^{\circ} \mathrm{C}\right)\end{array}$ & $\mathrm{n}$ & $\begin{array}{c}\text { Mass } \\
(\mathrm{g})\end{array}$ & $\begin{array}{c}\text { Standard } \\
\text { length }(\mathrm{cm})\end{array}$ & $\begin{array}{c}\text { Critical } \\
\text { limit }\left({ }^{\circ} \mathrm{C}\right)\end{array}$ \\
\hline $\begin{array}{l}\text { Critical thermal limits } \\
\text { Minima }\end{array}$ & & & & \\
17.8 & 4 & $46.6( \pm 33.89)$ & $9.1( \pm 2.77)$ & $9.9( \pm 0.56)^{\mathrm{a}}$ \\
23.0 & 4 & $56.3( \pm 17.99)$ & $11.1( \pm 0.87)$ & $11.4( \pm 0.37)^{\mathrm{b}}$ \\
29.0 & 4 & $63.8( \pm 14.18)$ & $10.2( \pm 1.92)$ & $13.2( \pm 0.56)^{\mathrm{c}}$ \\
31.1 & 4 & $34.4( \pm 7.12)$ & $9.7( \pm 1.08)$ & $13.8( \pm 0.10)^{\mathrm{c}}$ \\
Maxima & & & & \\
17.8 & 4 & $50.3( \pm 16.36)$ & $10.3( \pm 1.16)$ & $33.7( \pm 0.86)^{\mathrm{d}}$ \\
23.0 & 4 & $43.3( \pm 27.37)$ & $9.6( \pm 1.62)$ & $36.0( \pm 0.25)^{\mathrm{d}}$ \\
29.0 & 4 & $63.8( \pm 27.10)$ & $10.3( \pm 1.03)$ & $37.6( \pm 0.42)^{\mathrm{e}}$ \\
31.1 & 4 & $34.5( \pm 18.98)$ & $9.5( \pm 1.41)$ & $38.5( \pm 0.27)^{\mathrm{e}}$ \\
Cycling thermal maximum & & & \\
$24.0-30.5$ & 10 & $39.1( \pm 7.74)$ & $10.2( \pm 0.74)$ & $38.3( \pm 0.33)^{\mathrm{e}}$ \\
Chronic limits & & & & \\
Maximum & 3 & $32.0( \pm 0.01)$ & $9.9( \pm 1.25)$ & $32.0( \pm 0.01)$ \\
Minimum & 3 & $12.6( \pm 0.76)$ & $10.0( \pm 1.69)$ & $12.6( \pm 0.01)$ \\
\hline
\end{tabular}


gested that lionfish acclimated to the peak cycle temperature (Table 2). The heat tolerance value of $38.3^{\circ} \mathrm{C}$ for cycled fish was intermediate to CTmax of 37.6 and $38.5^{\circ} \mathrm{C}$ measured for lionfish acclimated at constant temperatures of 29.0 and $31.1^{\circ} \mathrm{C}$, respectively. An ANOVA comparing cycled and constant acclimation temperature treatment groups uncovered significant differences between CTmax $\left(F_{4,21}=\right.$ 93.4, $\mathrm{p}<0.0001)$. Tukey's multiple range test $(\alpha=$ 0.05 ) found that heat tolerance of cycled lionfish was significantly higher than CTmax values for the 2 low constant temperature acclimation treatments of 17.8 and $23.0^{\circ} \mathrm{C}$, but statistically similar to fish acclimated at 29.0 and $31.1^{\circ} \mathrm{C}$ for $2 \mathrm{wk}$.

\section{Thermal niche assessment}

Chronic and critical thermal tolerance endpoints provided the necessary relationships and ranges needed to define the polygonal niche boundaries that describe red lionfish thermal ecology. When acclimated at constant treatment temperatures within their thermal acclimation zone, lionfish exhibited CTmax ranging between 33.7 and $38.5^{\circ} \mathrm{C}$, and corresponding CTmin ranging between 9.9 and $13.8^{\circ} \mathrm{C}$ (Table 2). The average thermal scope, calculated as the mean difference between CTmax and CTmin across treatments, was also relatively large at $24.4 \pm$ $0.4^{\circ} \mathrm{C}$. A thermal niche constructed from the chronic and critical data produced a quadrilateral figure encompassing a total area of $469.6^{\circ} \mathrm{C}^{2}$ (Fig. 2). Division of the polygon resulted in upper and lower areas of acquired tolerance with somewhat similar areas of 64.7 and $55.4^{\circ} \mathrm{C}^{2}$, respectively. The acquired tolerance zone areas together account for about $26 \%$ of the total polygonal area. The area between the upper and lower acquired zones defines the species' intrinsic tolerance zone, which comprised $349.5^{\circ} \mathrm{C}^{2}$, or approximately $74 \%$ of the total polygonal area, and resulted in an intrinsic to acquired ratio of approximately $3: 1$.

\section{Final temperature preferendum}

The initial response of lionfish placed into the thermal gradient was to explore their surroundings, visiting the full range of chamber temperatures (i.e. 20 to $27^{\circ} \mathrm{C}$ ). The exploration period lasted for approximately $1 \mathrm{~h}$, after which fish activity and the range of temperatures selected were both markedly reduced as fish approached their final thermal preferendum.

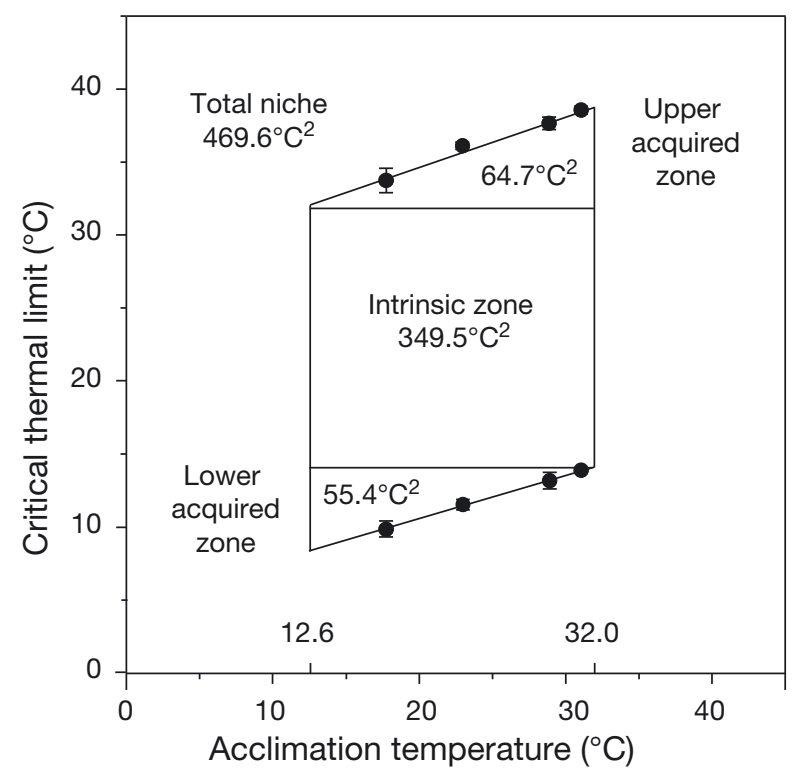

Fig. 2. Thermal tolerance niche for red lionfish Pterois volitans captured off Hoga Island, southeast Sulawesi, Indonesia. The polygonal upper and lower boundaries are defined by the critical thermal maxima and minima points (error bars represent $1 \mathrm{SD}$ ). The vertical lines at 12.6 and $32.0^{\circ} \mathrm{C}$ represent the lower and upper chronic temperatures that define the acclimation range. The total niche area is divided into intrinsic, as well as upper and lower acquired tolerance zones. The intrinsic zone defines the range of temperatures (ca. $15-30^{\circ} \mathrm{C}$ ) lionfish survive regardless of previous thermal history, whereas acquired zones represent additional upper or lower thermal tolerance gained through acclimation. Each zone is quantified by its area expressed as ${ }^{\circ} \mathrm{C}^{2}$

Once established, lionfish demonstrated high fidelity to their preferred temperature, even changing position to accommodate slight thermal shifts in chamber water temperatures from daytime to nighttime, further suggesting that fish were responding to thermal cues as opposed to chamber characteristics. The grand means calculated from individual lionfish trial mean, median, and mode temperatures were 23.6 $( \pm 0.9), 23.4( \pm 1.0)$, and $23.2( \pm 1.5)^{\circ} \mathrm{C}$, respectively (Table 3).

\section{Metabolic rate and temperature sensitivity $\left(Q_{10}\right)$}

Acute increases in environmental temperature elicited an increase in lionfish metabolic rates. Metabolic rates of resting, fasting lionfish rose from 0.023 $( \pm 0.009)$ to $0.039( \pm 0.017) \mathrm{mg} \mathrm{O}_{2} \mathrm{~min}^{-1}$ as water temperatures were acutely increased from 20.3 to $28.4^{\circ} \mathrm{C}$. A paired, 1-tailed $t$-test showed significant increases in total metabolic demand with the acute rise in temperature $\left(t_{9}=-3.44, \mathrm{p}=0.007\right)$. Tempera- 
Table 3. Summary data for routine resting metabolic rates (total $\mathrm{mg} \mathrm{O}_{2} \mathrm{~min}^{-1}$ ) and thermal preference endpoints (i.e. mean, median, mode, highest, and lowest temperatures) of red lionfish Pterois volitans. Data are mean \pm SD. Differing superscripts for total metabolic values indicate significant differences at $\alpha=0.05$

\begin{tabular}{|c|c|c|c|c|c|c|c|}
\hline $\begin{array}{l}\text { Te } \\
\mathrm{n}\end{array}$ & $\begin{array}{l}\text { Mass (g) } \\
\text { Mature quotie }\end{array}$ & $\begin{array}{l}\text { xperiment } \\
\text { Standard length }\end{array}$ & $(\mathrm{cm})$ & erature $\left({ }^{\circ} \mathrm{C}\right)$ & Total metaboli & te $\left(\mathrm{mg} \mathrm{O} \mathrm{O}_{2} \min ^{-1}\right)$ & $Q_{10}$ \\
\hline 10 & $22.0( \pm 6.89)$ & $8.2( \pm 0.80)$ & \multicolumn{2}{|c|}{$\begin{array}{l}20.3( \pm 0.28) \\
28.4( \pm 0.38)\end{array}$} & \multicolumn{2}{|c|}{$\begin{array}{l}0.023( \pm 0.009)^{\mathrm{a}} \\
0.039( \pm 0.017)^{\mathrm{b}}\end{array}$} & 1.91 \\
\hline \multicolumn{8}{|c|}{ Temperature preference experiment } \\
\hline $\mathrm{n}$ & $\begin{array}{l}\text { Mass } \\
(\mathrm{g})\end{array}$ & $\begin{array}{l}\text { Standard } \\
\text { length }(\mathrm{cm})\end{array}$ & $\begin{array}{l}\text { Mean } \\
\left({ }^{\circ} \mathrm{C}\right)\end{array}$ & $\begin{array}{l}\text { Median } \\
\left({ }^{\circ} \mathrm{C}\right)\end{array}$ & $\begin{array}{l}\text { Mode } \\
\left({ }^{\circ} \mathrm{C}\right)\end{array}$ & $\begin{array}{l}\text { Maximum } \\
\left({ }^{\circ} \mathrm{C}\right)\end{array}$ & $\underset{\left({ }^{\circ} \mathrm{C}\right)}{\operatorname{Minimum}}$ \\
\hline 10 & $49.1( \pm 14.66)$ & $10.5( \pm 0.67)$ & $23.6( \pm 0.93)$ & $23.4( \pm 0.97)$ & $23.2( \pm 1.46)$ & $26.5( \pm 0.96)$ & $21.3( \pm 1.00)$ \\
\hline
\end{tabular}

ture sensitivity measured as a temperature quotient $\left(Q_{10}\right)$ value was 1.91 , suggesting that lionfish metabolic demand increased by $90 \%$ with each acute $10^{\circ} \mathrm{C}$ increase in ambient temperature (Table 3).

\section{DISCUSSION}

While the family Scorpaenidae is largely comprised of fishes inhabiting stable, tropical habitats (Eschmeyer et al. 2016), some lionfishes have successfully colonized areas where water temperatures intermittently fall well below their preferred temperature range $\left(\sim 23^{\circ} \mathrm{C}\right.$ for red lionfish). Current laboratory data imply that red lionfish and devil firefish will acclimate to chronic minimum temperatures between approximately 13 (present study) and $16^{\circ} \mathrm{C}$ (Kimball et al. 2004), as long as the rate of temperature decline is slow enough to keep pace with acclimation $\left(\sim 1^{\circ} \mathrm{C}\right.$ $\mathrm{d}^{-1}$ or less). Furthermore, red lionfish acclimated to $\sim 18^{\circ} \mathrm{C}$ or lower continue to execute coordinated escape responses down to their CTmin temperature of $\sim 10^{\circ} \mathrm{C}$ (Barker 2015, this study). Mortality observations of lionfish populations inhabiting waters where temperatures periodically reach low physiological limits not only support the laboratory thermal findings, but also identify 2 additional eurythermic lionfishes. In February 1961, the Seto Marine Biological Laboratory in Wakayama Prefecture, Japan, experienced a severe cold weather event that reduced sea temperatures to $11.5 \pm 0.5^{\circ} \mathrm{C}$ for $4 \mathrm{~d}$ (Tokioka 1961). A total of 51 species were stunned or killed during the event, including the luna lionfish. A second, more severe cold front at Seto Laboratory between 14 January and 5 February 1968 dropped sea temperatures below $12^{\circ} \mathrm{C}$ for 5 consecutive days (18-23 January), reaching a low of $10.1^{\circ} \mathrm{C}$ on 19 January and holding temperatures below the winter average of $15^{\circ} \mathrm{C}$ for 3 wk (Araga \& Tanase 1968). Among the thousands of fishes killed by cold were 21 red lionfish, 23 luna lionfish, and 217 peppermint lionfish. Peppermint lionfish were killed within the first week of the cold front, whereas red lionfish and luna lionfish died in lower numbers and did not appear until the third week of the cold snap. While the total percentage of lionfish killed in each population cannot be estimated from mortality data alone, the Seto reports (Tokioka 1961, Araga \& Tanase 1968) confirm that, in addition to red lionfish and devil firefish, at least 2 other lionfish species support populations in waters where unpredictable weather can rapidly reduce temperatures to lethal levels. The field data also point out that lionfish species may respond differently to similar thermal events. Peppermint lionfish were most susceptible to cold temperatures, dying quickly and in large numbers, whereas red lionfish appeared more resistant to low temperatures, surviving well below their feeding cessation point $\left(12.6^{\circ} \mathrm{C}\right)$ and likely coming very near their lowest measured CTmin temperature of $9.9^{\circ} \mathrm{C}$. The ability to escape rapidly deteriorating thermal conditions and to survive prolonged exposure to lethal temperatures for several days may help explain the persistence of lionfish populations in areas of the US mid-Atlantic Seaboard, and may have implication for the spread of red lionfish into novel habitats along southern coastal Brazil.

Laboratory studies of scorpaenid thermal ecology are virtually nonexistent, and the few cold tolerance data available (Kimball et al. 2004) are typically used only to estimate the potential spread of invasive red lionfish and/or devil firefish, without a larger discussion of what thermal adaptations make these species good colonizers across a range of thermal habitats. Red lionfish exhibit 3 interrelated thermal niche features that leave them well suited for capricious thermal environments, including a relatively large intrinsic niche area, a distinct cold-shifted lower 
acclimation boundary, and a strong acclimation response. The total polygonal area of $470^{\circ} \mathrm{C}^{2}$ seen in red lionfish is moderately larger than niche areas determined by Eme \& Bennett (2009) for the syntopic white-tailed humbug Dascyllus aruanus $\left(443^{\circ} \mathrm{C}^{2}\right)$ and nine-banded cardinalfish Apogon novemfasciatus $\left(408^{\circ} \mathrm{C}^{2}\right)$. All 3 species have similar intrinsic scope values between 16 and $18^{\circ} \mathrm{C}$ (i.e. difference between the intrinsic zone upper and lower ordinate boundary temperatures), and the upper acclimation boundary locations are similar for all 3 species as well. Compared to the other 2 fishes, however, the lower acclimation boundary of lionfish is cold-shifted left by approximately $5^{\circ} \mathrm{C}$, and the CTmin lower limit is decreased by about $3^{\circ} \mathrm{C}$. These positional differences account for both a larger polygonal area (i.e. higher degree of eurythermicity) and lower cold tolerance values seen in lionfish. Enhanced low temperature tolerance would explain why red lionfish are so successful in exploiting cooler temperatures in novel and native habitats.

Changes in temperature impair normal muscle and neuronal function in fish by disrupting lipid membranes and ion exchange, which in turn may affect behavior and capacity to react to prey and predators. Most fishes have the ability to acclimate across a select range of temperatures by altering molecular and biochemical pathways to optimize physiological performance (see reviews by Hochachka \& Somero 2002, Meyer-Rochow 2013). Several tropical species native to the Banda Sea, including red lionfish (present study), white-tailed humbugs, and nine-banded cardinalfish (Eme \& Bennett 2009), can alter critical CTmax or CTmin by approximately $12 \%$ (i.e. $25 \%$ of their niche area is gained through acclimation). The magnitude of the acclimation adjustment is dictated by the acclimation response ratio of heat or cold tolerance gained or lost per $1^{\circ} \mathrm{C}$ change in acclimation temperature. Red lionfish, white-tail humbug, and nine-banded cardinalfish all exhibit high acclimation response ratios of $\sim 0.35^{\circ} \mathrm{C}$. Lionfish that become trapped by rising temperatures and falling water levels may gain an additional level of protection by acclimating to the high end of the diel temperature cycle. As a result, lionfish are able to persist across a wide range of temperatures between 14 and $32^{\circ} \mathrm{C}$, as well as remain in areas where temperatures are rapidly cycling, such as tide pools or estuaries during tidal exchanges. The polygonal conformation seen in red lionfish may explain mortality patterns of lionfishes killed by cold in their natural environment, as well as their successful invasions into novel environments.
While thermal niche analysis provides insights into how lionfish interact with their thermal environment, comparing individual polygonal components of invasive Atlantic populations to a native Banda Sea population can highlight differences in thermal attributes or compensatory strategies between groups. Kimball et al. (2004) ran a series of low temperature tolerance experiments on a mixed group of red lionfish and devil firefish presumably imported from Indonesia (possibly Sumatra). In an experiment similar to our chronic minimum trials (Table 2), a lionfish/firefish group exposed to a temperature decrease of $1^{\circ} \mathrm{C} \mathrm{d}^{-1}$ stopped eating at $15.3^{\circ} \mathrm{C}$ and reached their lethal limit at $10.7^{\circ} \mathrm{C}$. By comparison, our estimated chronic minimum value of $12.6 \pm$ $0.76^{\circ} \mathrm{C}$ (determined using a loss of equilibrium) falls midway between the feeding cessation and lethal minimum temperatures reported by Kimball et al. (2004). Kimball et al. (2004) did not determine a chronic maximum, so it is unclear whether the $32^{\circ} \mathrm{C}$ chronic value for red lionfish in the present study would also be representative of a mixed population of red lionfish and devil firefish. Kimball et al. (2004) also reported that acclimation temperature had no effect on thermal tolerance of fish in their experiments. Conversely, both Banda Sea lionfish (present study), as well as south Florida Atlantic lionfish (Barker 2015) displayed strong acclimation responses during CTmax/CTmin trials. Barker (2015) reported respective upper and lower acclimation response ratios of 0.50 and 0.42 for south Florida lionfish, markedly higher values than the ratios of 0.37 and 0.30 seen in lionfish in our study. In addition, south Florida lionfish exhibited a higher total polygonal area $\left(573^{\circ} \mathrm{C}^{2}\right)$, than Banda Sea lionfish (total polygonal area of $470^{\circ} \mathrm{C}^{2}$ ). Taken at face value, the existing thermal data suggest that south Florida lionfish are somewhat more eurythermic, and gain 33\% more heat or cold tolerance than lionfish in our study when exposed to similar water temperature changes.

Thermal ecology results from our study, as well as those of Barker (2015) and Kimball et al. (2004), are similar in some respects, but differ in others. For example, while the lower chronic loss of equilibrium temperature in the present study falls, as expected, between cessation of feeding and lethal temperatures reported by Kimball et al. (2004), the absence of an acclimation temperature response conflicts with results from the present study as well as those of Barker (2015). Conversely, while our CTmin and CTmax values show generally good agreement with Barker's (2015) values, lionfish polygonal niche areas in the 2 studies differ markedly, likely attributable to 
variations in methodology. The acclimation temperature experiments of Kimball et al. (2004) used slow rates of water temperature change of $1^{\circ} \mathrm{C} \mathrm{d}^{-1}$, allowing fish to acclimate during the treatment and wiping out any acclimation temperature effects, whereas Barker (2015) likely inflated the acclimation range and niche area of Florida lionfish somewhat by substituting a chronic death endpoint of $10.7^{\circ} \mathrm{C}$ for the lower niche boundary (see Kimball et al. 2004), and assuming an upper acclimation boundary of $35^{\circ} \mathrm{C}$. Biological factors may have also influenced lionfish population thermal responses. Compared to populations from their native range, Atlantic lionfish exhibit a large decrease in genetic diversity, suggesting the group arose from a relatively small number of founding individuals (Hamner et al. 2007, Betancur-R. et al. 2011). A strong founder effect increases the likelihood of rapid genetic drift in local populations (Planes \& Lecaillon 1998) and could provide a mechanism for rapid changes in thermal tolerance in lionfish introduced into Atlantic waters.

Fishes in heterogeneous thermal environments generally seek out a preferred temperature at which metabolic performance is optimized (Fry 1947). Thermal preference values may differ among species within the same geographic range, perhaps due to differences in microhabitat conditions or biological factors such as life stage (Cox et al. 1974, Komoroske et al. 2014). Reynolds \& Casterlin (1980) reported a $4^{\circ} \mathrm{C}$ range in final preferred temperatures for selected tropical Indo-Pacific reef fishes. Yellow tang Zebrasoma flavescens had a final preferendum of $21^{\circ} \mathrm{C}$, while yellow-spotted triggerfish Balistes fuscus, orangespine unicornfish Naso lituratus, and humpback grouper Cromileptes altivelis exhibited somewhat higher preferenda between 23 and $25^{\circ} \mathrm{C}$ (Reynolds \& Casterlin 1981). The median preferred temperature for red lionfish in our experiments $\left(23.4^{\circ} \mathrm{C}\right)$ shows good agreement with these tropical Indo-Pacific species. The final thermal preferendum for lionfish is very nearly the midpoint between the species' upper and lower chronic temperatures. In the only other preference study on lionfish, Barker (2015) estimated a final preferred temperature between approximately 28 and $30^{\circ} \mathrm{C}$ for invasive lionfish from Key West, Florida. This range is approximately $5^{\circ} \mathrm{C}$ warmer than that of native lionfish in our experiments, and 4 to $8^{\circ} \mathrm{C}$ higher than the values listed for other Indo-Pacific fishes. One explanation for the high preferred temperature may be the shuttlebox technology used in the experiments of Barker (2015), which can be prone to acclimation overshoot in trials lasting less than 4 d (Reynolds 1978). Life stage could also play a role. For example, juvenile bluegill Lepomis macrochirus and delta smelt Нypomesus transpacificus have inherently higher thermal tolerance limits compared to adults (Cox et al. 1974, Komoroske et al. 2014). Lionfish in the shuttlebox trials were on average smaller than fish in our study, and it is possible that a right-shift in the upper temperature tolerance boundary could have increased the preferred temperature of juvenile fish. Although previous lionfish studies have not looked at the relationship between life stage and thermal tolerance limits, an important contribution to understanding the species' thermal ecology would be to establish whether egg and embryological development at different temperatures have been affected by the small group of founders responsible for the Atlantic population.

At temperatures outside the preferred range, acute increases or decreases in metabolic rate may reduce the overall metabolic efficiency of a fish. The degree of metabolic thermal sensitivity (quantified as the temperature quotient or $Q_{10}$ ) can vary considerably among species. For example, common goby Bathygobius fuscus and sand flat goby Bathygobius sp. from tropical Indo-Pacific tidal pool environments showed no notable changes in metabolic rate $\left(Q_{10}\right.$ values of 1$)$ when exposed to simulated temperature extremes experienced during tidal exchanges. These fishes likely retain multiple, redundant metabolic pathways that stabilize metabolic efficiency during rapidly changing thermal conditions (Eme \& Bennett 2009). On the other hand, fishes inhabiting environments where water temperatures are predictable and seasonably stable usually exhibit a 2 - to 3 -fold (i.e. $Q_{10}$ of 2 to 3) change in metabolic rate with a $10^{\circ} \mathrm{C}$ shift in water temperature (Schmidt-Nielsen 1997). Metabolic rates of lionfish acutely transferred to temperatures approximately $4^{\circ} \mathrm{C}$ above $\left(28.4^{\circ} \mathrm{C}\right)$ and below $\left(20.3^{\circ} \mathrm{C}\right)$ their final preferred temperature $\left(23.5^{\circ} \mathrm{C}\right)$ yielded a $Q_{10}$ value of 1.91 . Cerino et al. (2013) reported a somewhat higher $Q_{10}$ value of 2.33 for invasive North Carolina lionfish measured between 14 and $32^{\circ} \mathrm{C}$. Native Banda Sea lionfish also have lower temperature quotient values than other syntopic reef species such as the nine-banded cardinalfish (2.29) and the white-tail humbug (2.65) (Eme \& Bennett 2009). The collective $Q_{10}$ data would suggest that the native lionfish population may recognize a modest metabolic advantage when moving from lower to higher temperatures. Long-term metabolic elevations are untenable, however, and over time fishes may reduce their metabolic burden by altering their physiology to work more efficiently at the new water 
temperatures (Precht et al. 1973, Hochachka \& Somero 2002, Meyer-Rochow 2013).

The scorpaenids are specious, widespread, and ecologically important, yet very little is known about the group's thermal physiological ecology. Indeed, if not for the lionfish 'invasion,' it is quite likely that we would know virtually nothing about the temperature requirements of scorpionfishes. Furthermore, what is known about scorpaenid thermal ecology is based almost exclusively on a limited data set collected from red lionfish, and to a lesser degree, devil firefish. It remains unclear whether the adaptive thermal strategies seen in these species are representative for the group overall. While a large percentage of scorpaenids are found in warm tropical waters, it is likely that a substantial number of these species could, as with red lionfish, survive in areas of much cooler temperatures than those they currently occupy. It also seems likely that species having successfully made the transition to cold environments would exhibit a very different thermal profile from that seen in red lionfish. Additionally, combined effects of important environmental factors such as temperature and salinity on lionfish thermal tolerance or preference are virtually unknown, yet lionfish inhabit a variety of temperature-salinity conditions - from the northern Red Sea with relatively low temperatures $\left(\sim 26^{\circ}\right)$ and high salinities (up to $41 \%$ ), to shallow tropical estuaries with high temperatures and low salinities and multi-factor analysis could provide worthwhile insights into lionfish thermal acclimation dynamics. More work remains to be done before we will begin to understand the range and variability of thermal adaptations in this interesting group.

Acknowledgements. We thank Operation Wallacea, the Ernest Hill Fellowship, and the University of California Agricultural Experiment Station (grant 2098-H to N.A.F.) for providing funding for this project. All animals in this study were treated in accordance with guidelines approved by the University of West Florida Animal Care and Use Committee (Protocol 2012-006). We also thank David Kracov for funding and inspiration.

\section{LITERATURE CITED}

Albins MA, Hixon MA (2008) Invasive Indo-Pacific lionfish Pterois volitans reduce recruitment of Atlantic coral-reef fishes. Mar Ecol Prog Ser 367:233-238

Albins MA, Hixon MA (2013) Worst case scenario: potential long-term effects of invasive predatory lionfish (Pterois volitans) on Atlantic and Caribbean coral-reef communities. Environ Biol Fishes 96:1151-1157

Albins MA, Lyons PJ (2012) Invasive red lionfish Pterois volitans blow directed jets of water at prey fish. Mar Ecol Prog Ser 448:1-5
Allen GR, Eschmeyer WN (1973) Turkeyfishes at Eniwetok. Pac Discovery 26:3-11

Araga C, Tanase H (1968) Further record of winter fish stranding in the vicinity of Seto. Publ Seto Mar Biol Lab 16:207-218

Arculeo M, Brutto SL (2014) New contribution to the systematic status of various Mediterranean scorpionfish, as inferred from a mitochondrial DNA sequence. Rev Biol Mar Oceanogr 49:367-371

Barbour AB, Montgomery ML, Adamson AA, Diaz-Ferguson E, Silliman BR (2010) Mangrove use by the invasive lionfish Pterois volitans. Mar Ecol Prog Ser 401:291-294

Barker B (2015) Thermal preferences and critical temperature regimes of the western north Atlantic invasive lionfish complex (Pterois spp.). MSc thesis, Nova Southeastern University, Fort Lauderdale, FL

*Becker CD, Genoway RG (1979) Evaluation of the critical thermal maximum for determining thermal tolerance of freshwater fish. Environ Biol Fishes 4:245-256

Beckley LE (2000) Species composition and recruitment of tidal pool fishes in KwaZulu-Natal, South Africa. Afr Zool 35:29-34

Beitinger TL, Bennett WA, McCauley RW (2000) Temperature tolerances of North American freshwater fishes exposed to dynamic changes in temperature. Environ Biol Fishes 58:237-275

Bennett WA (2010) Extreme physiology of intertidal fishes of the Wakatobi. In: Unsworth RKF, Clifton J, Smith DJ (eds) Marine research and conservation in the Coral Triangle: the Wakatobi National Park. Nova Science Publishers, Hauppage, NY, p 113-130

Bennett WA, Beitinger TL (1997) Temperature tolerance of the sheepshead minnow, Cyprinodon variegatus. Copeia 1997:77-87

Berg LS (1958) System der rezenten und fossilen Fischartigen und Fische. VEB Verlag der Wissenschaften, Berlin

Betancur-R. R, Hines A, Acero P, Ortí G, Wilbur AE, Freshwater DW (2011) Reconstructing the lionfish invasion: insights into Greater Caribbean biogeography. J Biogeogr 38:1281-1293

* Bilgin S, Çelik ES (2009) Age, growth and reproduction of the black scorpionfish, Scorpaena porcus (Pisces, Scorpaenidae), on the Black Sea coast of Turkey. J Appl Ichthyol 25:55-60

Butler JL, Love MS, Laidig TE (2012) A guide to the rockfishes, thornyheads, and scorpionfishes of the northeast Pacific. University of California Press, Oakland, CA

* Carlson JK, Parsons GR (1999) Seasonal differences in routine oxygen consumption rates of the bonnethead shark. J Fish Biol 55:876-879

Cech JJ Jr (1990) Respirometry In: Schreck CB, Moyle PB (eds) Methods for fish biology. American Fisheries Society, Bethesda, MD, p 335-363

Cerino D, Overton AS, Rice JA, Morris JA Jr (2013) Bioenergetics and trophic impacts of the invasive Indo-Pacific lionfish. Trans Am Fish Soc 142:1522-1534

Claydon JAB, Calosso MC, Traiger SB (2012) Progression of invasive lionfish in seagrass, mangrove and reef habitats. Mar Ecol Prog Ser 448:119-129

Coutant CC (1977) Compilation of temperature preference data. J Fish Res Board Can 34:739-745

Cowles RB, Bogert CM (1944) A preliminary study of the thermal requirements of desert reptiles. Bull Am Mus Nat Hist 83:261-296

Cox GW (1990) Laboratory manual of general ecology, 6th 
edn. William C. Brown Publishers, Dubuque, IA

Cox DK, Gibbons JW, Sharitz RR (1974) Effects of three heating rates on the critical thermal maximum of bluegill. CONF-730505. Oak Ridge National Lab, TN, and Savannah River Ecology Lab, Aiken, SC

Cure K, McIlwain JL, Hixon MA (2014) Habitat plasticity in native Pacific red lionfish Pterois volitans facilitates successful invasion of the Atlantic. Mar Ecol Prog Ser 506: 243-253

Dabruzzi TF, Bennett WA, Rummer JL, Fangue NA (2013) Juvenile ribbontail stingray, Taeniura lymma (Forsskål, 1775) (Chondrichthyes, Dasyatidae), demonstrate a unique suite of physiological adaptations to survive hyperthermic nursery conditions. Hydrobiologia 701:37-49

* Darling ES, Green SJ, O'Leary JK, Côté IM (2011) IndoPacific lionfish are larger and more abundant on invaded reefs: a comparison of Kenyan and Bahamian lionfish populations. Biol Invasions 13:2045-2051

* Di Santo V, Bennett WA (2011) Is post-feeding thermotaxis advantageous in elasmobranch fishes? J Fish Biol 78: 195-207

Eddy C, Pitt J, Morris JA Jr, Smith S, Goodbody-Gringley G, Bernal D (2016) Diet of invasive lionfish (Pterois volitans and P. miles) in Bermuda. Mar Ecol Prog Ser 558: 193-206

Edwards MA, Frazer TK, Jacoby CA (2014) Age and growth of invasive lionfish (Pterois spp.) in the Caribbean Sea, with implications for management. Bull Mar Sci 90: 953-966

Eme J, Bennett WA (2009) Critical thermal tolerance polygons of tropical marine fishes from Sulawesi, Indonesia. J Therm Biol 34:220-225

Eschmeyer WN, Herald ES, Hammann H (1983) A field guide to Pacific coast fishes of North America. Houghton Mifflin Company, Boston, MA

Eschmeyer WN, Fricke R, van der Laan R (2016) Cata$\log$ of fishes: genera, species, references. http:// researcharchive.calacademy.org/research/ichthyology/ catalog/fishcatmain.asp (accessed 12 June 2016)

Fangue NA, Bennett WA (2003) Thermal tolerance responses of laboratory-acclimated and seasonally acclimatized Atlantic stingray, Dasyatis sabina. Copeia 2003: 315-325

Fangue NA, Wunderly MA, Dabruzzi TF, Bennett WA (2014) Asymmetric thermal acclimation responses allow sheepshead minnow Cyprinodon variegatus to cope with rapidly changing temperatures. Physiol Biochem Zool 87:805-816

Ferreira CE, Luiz OJ, Floeter SR, Lucena MB, Barbosa MC, Rocha CR, Rocha LA (2015) First record of invasive lionfish (Pterois volitans) for the Brazilian coast. PLOS ONE 10:e0123002

Freshwater DW, Hines A, Parham S, Wilbur A and others (2009) Mitochondrial control region sequence analyses indicate dispersal from the US East Coast as the source of the invasive Indo-Pacific lionfish Pterois volitans in the Bahamas. Mar Biol 156:1213-1221

Fry FEJ (1947) Effects of the environment on animal activity. Univ Tor Stud Biol Ser 55:1-62

* Green SJ, Côté IM (2009) Record densities of Indo-Pacific lionfish on Bahamian coral reefs. Coral Reefs 28:107

* Green SJ, Akins JL, Maljkovi A, Côté IM (2012) Invasive lionfish drive Atlantic coral reef fish declines. PLOS ONE 7:e32596

*Hackerott S, Valdivia A, Green SJ, Côté IM and others
(2013) Native predators do not influence invasion success of Pacific lionfish on Caribbean reefs. PLOS ONE 8: e68259

*Hamner RM, Freshwater DW, Whitfield PE (2007) Mitochondrial cytochrome $b$ analysis reveals two invasive lionfish species with strong founder effects in the western Atlantic. J Fish Biol 71:214-222

* Harms-Tuohy CA, Schizas NV, Appeldoorn RS (2016) Use of DNA metabarcoding for stomach content analysis in the invasive lionfish Pterois volitans in Puerto Rico. Mar Ecol Prog Ser 558:181-191

*Hixon MA, Beets JP (1993) Predation, prey refuges, and the structure of coral-reef fish assemblages. Ecol Monogr 63: 77-101

Hochachka PW, Somero GN (2002) Biochemical adaptation. Oxford University Press, New York, NY

* Hopkins TE, Cech JJ (1994) Effect of temperature on oxygen consumption of the bat ray, Myliobatis californica (Chondrichthyes, Myliobatididae). Copeia 1994:529-532

Hureau JC, Litvinenko NI (1986) Scorpaenidae. In: Whitehead PJP, Bauchot ML, Hureau JC, Nielsen J, Tortonese E (eds) Fishes of the North-eastern Atlantic and the Mediterranean, Vol 3. UNESCO, Paris, p 1211-1229

* Ingeman KE (2016) Lionfish cause increased mortality rates and drive local extirpation of native prey. Mar Ecol Prog Ser 558:235-245

Johnston MW, Purkis SJ (2011) Spatial analysis of the invasion of lionfish in the western Atlantic and Caribbean. Mar Pollut Bull 62:1218-1226

Johnston MW, Purkis SJ (2014) Are lionfish set for a Mediterranean invasion? Modelling explains why this is unlikely to occur. Mar Pollut Bull 88:138-147

Johnston MW, Purkis SJ (2015) Hurricanes accelerated the Florida-Bahamas lionfish invasion. Glob Change Biol 21: 2249-2260

* Jud ZR, Layman CA (2012) Site fidelity and movement patterns of invasive lionfish, Pterois spp., in a Florida estuary. J Exp Mar Biol Ecol 414-415:69-74

* Jud ZR, Nichols PK, Layman CA (2015) Broad salinity tolerance in the invasive lionfish Pterois spp. may facilitate estuarine colonization. Environ Biol Fishes 98:135-143

K Kimball ME, Miller JM, Whitfield PE, Hare JA (2004) Thermal tolerance and potential distribution of invasive lionfish (Pterois volitans/miles complex) on the east coast of the United States. Mar Ecol Prog Ser 283:269-278

Komoroske LM, Connon RE, Lindberg J, Cheng BS, Castillo G, Hasenbein M, Fangue NA (2014) Ontogeny influences sensitivity to climate change stressors in an endangered fish. Conserv Physiol 2:cou008

Kulbicki M, Beets J, Chabanet P, Cure K and others (2012) Distributions of Indo-Pacific lionfishes Pterois spp. in their native ranges: implications for the Atlantic invasion. Mar Ecol Prog Ser 446:189-205

* Layman CA, Jud ZR, Nichols P (2014) Lionfish alter benthic invertebrate assemblages in patch habitats of a subtropical estuary. Mar Biol 161:2179-2182

K Lesser MP, Slattery M (2011) Phase shift to algal dominated communities at mesophotic depths associated with lionfish (Pterois volitans) invasion on a Bahamian coral reef. Biol Invasions 13:1855-1868

ㄴönnstedt OM, Ferrari MC, Chivers DP (2014) Lionfish predators use flared fin displays to initiate cooperative hunting. Biol Lett 10:20140281

Love MS, Axell B, Morris P, Collins R, Brooks A (1987) Life history and fishery of the California scorpionfish, Scor- 
paena guttata, within the Southern California Bight. Fish Bull 85:99-116

Meister HS, Wyanski DM, Loefer JK, Ross SW, Quattrini AM, Sulak KJ (2005) Further evidence for the invasion and establishment of Pterois volitans (Teleostei: Scorpaenidae) along the Atlantic coast of the United States. Southeast Nat 4:193-206

Meyer-Rochow VB (2013) Thermal pollution: general effects and effects on cellular membranes and organelles in particular. In: Allodi S, Nazari EM (eds) Exploring themes on aquatic toxicology. Research Signpost Publishing, Trivandrum, p 1-34

Morris JA Jr, Akins JL (2009) Feeding ecology of invasive lionfish (Pterois volitans) in the Bahamian archipelago. Environ Biol Fishes 86:389-398

Morris JA Jr, Whitfield PE (2009) Biology, ecology, control and management of the invasive Indo-Pacific lionfish: an updated integrated assessment. Tech Memo NOS NCCOS 99. NOAA, Beaufort, NC

Motomura H, Bearez P, Causse R (2011) Review of IndoPacific specimens of the subfamily Scorpaeninae (Scorpaenidae), deposited in the Museum national d'Histoire naturelle, Paris, with description of a new species of Neomerinthe. Cybium 35:55-74

Neer JA, Carlson JK, Thompson BA (2006) Standard oxygen consumption of seasonally acclimatized cownose rays, Rhinoptera bonasus (Mitchill 1815), in the northern Gulf of Mexico. Fish Physiol Biochem 32:67-71

Nelson JS (2006) Fishes of the world, 4th edn. John Wiley \& Sons, Hoboken, NJ

NOAA (2016) National Centers for Environmental Information. https://www.nodc.noaa.gov/dsdt/cwtg/catl.html

Norton JG, Mason JE (2003) Environmental influences on species composition of the commercial harvest of finfish and invertebrates off California. Rep Calif Coop Ocean Fish Invest 44:123-133

Nuttall MF, Johnston MA, Eckert RJ, Embesi JA, Hickerson EL, Schmahl GP (2014) Lionfish (Pterois volitans [Linnaeus, 1758] and $P$. miles [Bennett, 1828]) records within mesophotic depth ranges on natural banks in the Northwestern Gulf of Mexico. BioInvasions Rec 3:111-115

Paladino FV, Spotila JR, Schubauer JP, Kowalski KT (1980) The critical thermal maximum: a technique used to elucidate physiological stress and adaptation in fishes. Rev Can Biol 39:115-122

Paulin CD (1982) Scorpionfishes of New Zealand (Pisces: Scorpaenidae). NZ J Zool 9:437-450

Pimiento C, Monaco E, Barbour A, Silliman B (2012) Predation on speared red lionfish, Pterois volitans, by spotted moray, Gymnothorax moringa. Fla Sci 76:391-394

Planes S, Lecaillon G (1998) Consequences of the founder effect in the genetic structure of introduced island coral reef fish populations. Biol J Linn Soc 63:537-552

Precht H, Christophersen J, Hensel H, Larcher W (1973) Temperature and life. Springer-Verlag, New York, NY

*Pusack TJ, Benkwitt CE, Cure K, Kindinger TL (2016) Invasive red lionfish (Pterois volitans) grow faster in the Atlantic Ocean than in their native Pacific range. Environ Biol Fishes 99:571-579

Editorial responsibility: Victor Benno Meyer-Rochow, Oulu, Finland
Raitsos DE, Beaugrand G, Georgopoulos D, Zenetos A, Pancucci-Papadopoulou AM, Theocharis A, Papathanassiou E (2010) Global climate change amplifies the entry of tropical species into the Eastern Mediterranean Sea. Limnol Oceanogr 55:1478-1484

Keynolds WW (1978) The final thermal preferendum of fishes: shuttling behavior and acclimation overshoot. Hydrobiologia 57:123-124

* Reynolds WW, Casterlin ME (1979) Behavioral thermoregulation and the 'final preferendum' paradigm. Am Zool 19: 211-224

* Reynolds WW, Casterlin ME (1980) Thermoregulatory behavior of a tropical reef fish, Zebrasoma flavescens. Oikos 34:356-358

* Reynolds WW, Casterlin ME (1981) Thermoregulatory behavior of the triggerfish Balistes fuscus in an electronic shuttlebox. Hydrobiologia 83:255-256

Schmidt-Nielsen K (1997) Animal physiology: adaptation and environment, 5th edn. Cambridge University Press, Cambridge

Schofield PJ (2009) Geographic extent and chronology of the invasion of non-native lionfish (Pterois volitans [Linnaeus 1758] and $P$. miles [Bennett 1828]) in the Western North Atlantic and Caribbean Sea. Aquat Invasions 4:473-479

Schofield PJ, Akins L, Gregoire-Lucente DR, Pawlitz RJ (2014) Invasive lionfish use a diversity of habitats in Florida. No. 2014-3032. US Geological Survey, Reston, VA

Schofield PJ, Huge DH, Rezek TC, Slone DH, Morris JA Jr (2015) Survival and growth of invasive Indo-Pacific lionfish at low salinities. Aquat Invasions 10:333-337

Spanier E (2000) Changes in the ichthyofauna of an artificial reef in the southeastern Mediterranean in one decade. Sci Mar 64:279-284

Steene R (2003) Reef fish identification: tropical Pacific. New World Publications, Jacksonville, FL

Steffensen JF (1989) Some errors in respirometry of aquatic breathers: how to avoid and correct for them. Fish Physiol Biochem 6:49-59

* Stevens ED (1992) Use of plastic materials in oxygenmeasuring systems. J Appl Physiol 72:801-804

Tokioka T (1961) Record of an unusual fish stranding in winter, with the list of stranded fishes identified by Prof. K. Matsubara. Publ Seto Mar Biol Lab 9:447-450

Vijay Anand PE, Pillai NGK (2007) Coral reef fish abundance and diversity of seagrass beds in Kavaratti atoll, Lakshadweep, India. Indian J Fish 54:11-20

Whitfield PE, Gardner T, Vives SP, Gilligan MR, Courtenay WR Jr, Ray GC, Hare JA (2002) Biological invasion of the Indo-Pacific lionfish Pterois volitans along the Atlantic coast of North America. Mar Ecol Prog Ser 235:289-297

Whitfield PE, Muñoz RC, Buckel CA, Degan BP, Freshwater DW, Hare JA (2014) Native fish community structure and Indo-Pacific lionfish Pterois volitans densities along a depth-temperature gradient in Onslow Bay, North Carolina, USA. Mar Ecol Prog Ser 509:241-254

Zenetos A, Çinar ME, Pancucci-Papadopoulou MA, Harmelin JG and others (2005) Annotated list of marine alien species in the Mediterranean with records of the worst invasive species. Mediterr Mar Sci 6:63-118

Submitted: July 6, 2016; Accepted: December 1, 2016

Proofs received from author(s): January 16, 2017 